\title{
RAS Family Gene
}

National Cancer Institute

\section{Source}

National Cancer Institute. RAS Family Gene. NCI Thesaurus. Code C25784.

A family of genes that encode structurally similar small GT Pases involved in a variety of signal transduction pathways. Mutation of genes in this family is associated with cancer. 